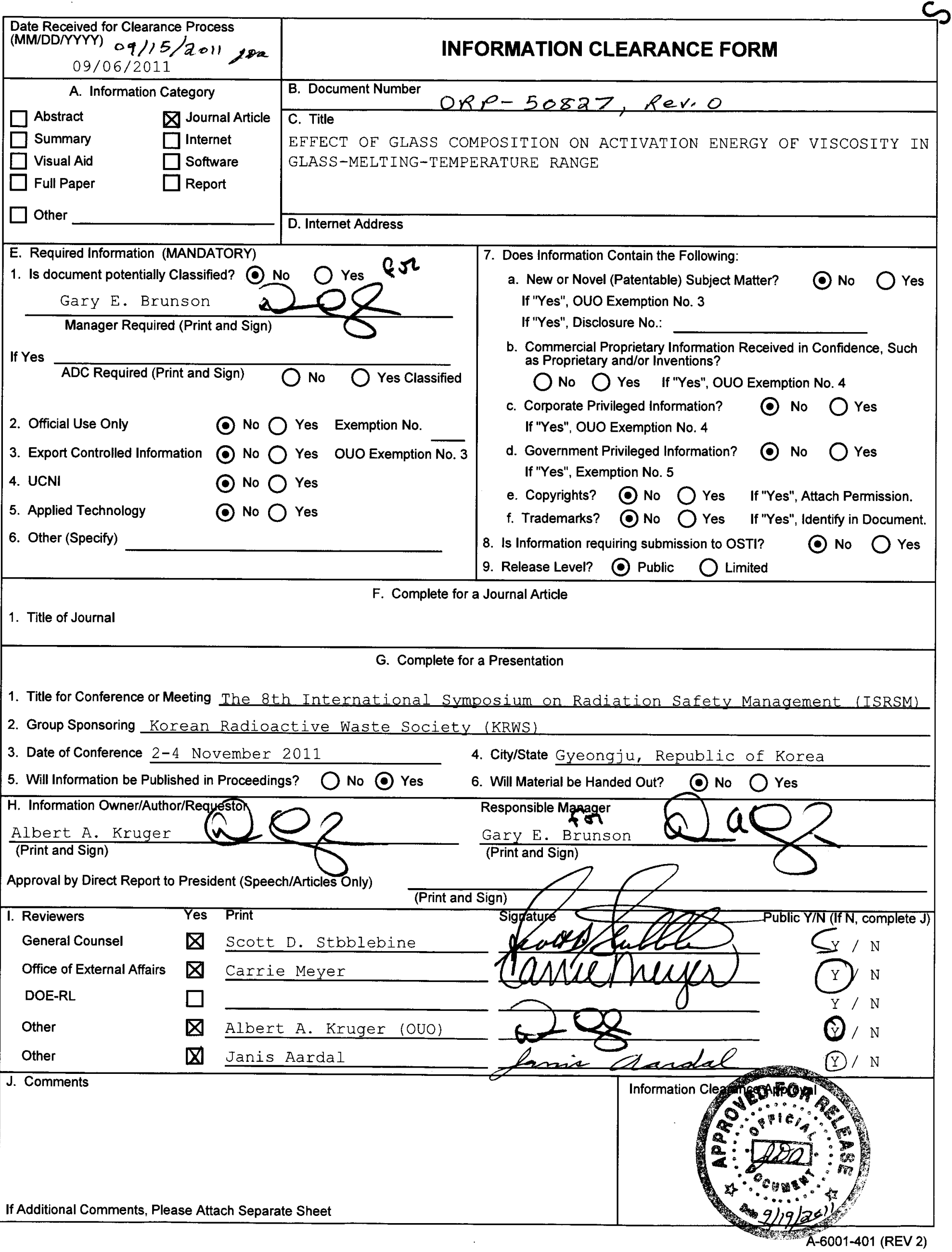


ORP-50827

Revision 0

\section{EFFECT OF GLASS \\ COMPOSITION ON \\ ACTIVATION ENERGY OF \\ VISCOSITY IN GLASS- \\ MELTING-TEMPERATURE \\ RANGE}

Prepared for the U.S. Department of Energy

Assistant Secretary for Environmental Management

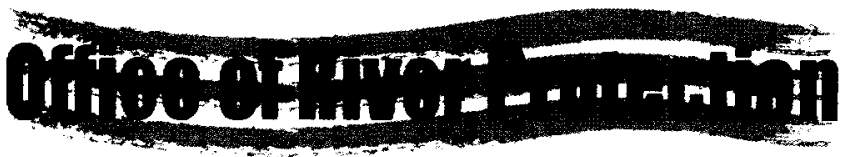

P.O. Box 450

Richland, Washington 99352 


\title{
EFFECT OF GLASS COMPOSITION ON ACTIVATION ENERGY OF VISCOSITY IN GLASS- MELTING-TEMPERATURE RANGE
}

\section{S. S. Han}

Division of Advanced Nuclear Engineering

Pohang University of Science and Technology

\author{
P. R. Hrma
}

Pacific Northwest National Laboratory

\author{
A. A. Kruger \\ Department of Energy - Office of River Protection \\ Date Published \\ September 2011 \\ To Be Presented at \\ Korean Radioactive Waste Society (KRWS) \\ Gyeongju, Republic of Korea \\ November 2-4, 2011 \\ Published in \\ The 8th International Symposium on Radiation Safety Management (ISRSM) \\ Prepared for the U.S. Department of Energy \\ Assistant Secretary for Environmental Management
}

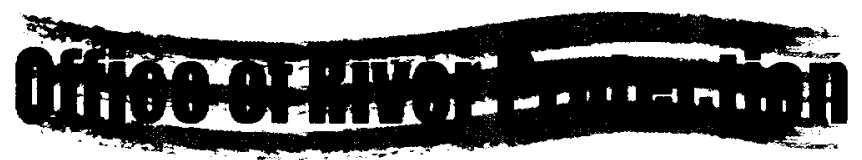

P.O. Box 450

Richland, Washington 99352

Copyright License

By acceptance of this article, the publisher and/or recipient acknowledges the U.S. Government's right to retain a nonexclusive, royalty-free license in and to any copyright covering this paper.

\section{Approud for Psbllk Rolease; $\frac{09 / 19 / 2011}{\text { Date }}$ 


\section{LEGAL DISCLAIMER}

This report was prepared as an account of work sponsored by an agency of the United States Government. Neither the United States Government nor any agency thereof, nor any of their employees, nor any of their contractors, subcontractors or their employees, makes any warranty, express or implied, or assumes any legal liability or responsibility for the accuracy, completeness, or any third party's use or the results of such use of any information, apparatus, product, or process disclosed, or represents that its use would not infringe privately owned rights. Reference herein to any specific commercial product, process, or service by trade name, trademark, manufacturer, or otherwise, does not necessarily constitute or imply its endorsement, recommendation, or favoring by the United

States Government or any agency thereof or its contractors or subcontractors. The views and opinions of authors expressed herein do not necessarily state or reflect those of the United States Government or any agency thereof.

This report has been reproduced from the best available copy. Available in paper copy. 


\title{
EFFECT OF GLASS COMPOSITION ON ACTIVATION ENERGY OF VISCOSITY IN GLASS-MELTING-TEMPERATURE RANGE
}

\author{
Sang-Soo $\operatorname{Han}^{(1)}$, Pavel Hrma ${ }^{(1,2)}$ \\ (1) Division of Advanced Nuclear Engineering, Pohang University of Science and Technology, Pohang, \\ Republic of Korea. \\ (2) Pacific Northwest National Laboratory, Richland, WA 99352. \\ pavel.hrma@pnl.gov
}

\begin{abstract}
Viscosity, a key property for glass processing, is a function of glass composition and temperature. Nuclear waste glasses must be formulated to obtain a desired viscosity at the melter processing temperature for each waste composition to be vitrified. Over the past decades, a large viscosity database has been accumulated at various laboratories in the US. The database, compiled at the Pacific Northwest National Laboratory, comprises over 1300 compositions with 83 components and 6800 viscosity data. We used this database to develop a mathematical model for the viscosity-composition relationship for viscosities lower than $1000 \mathrm{~Pa} \cdot \mathrm{s}$ that are important for the melting process. In this high-temperature range, the viscosity-temperature relationship has the form of an Arrhenius function, i.e., $\ln (\eta)=A+B / T$, where $\eta$ is the viscosity, $T$ is the absolute temperature, $A$ is a constant coefficient, and $B$ is the activation energy. We obtained $B$ for each data point and then fitted a first- or second-order model to $B$ as a function of glass composition while $A$ was kept constant for all glasses. Altogether, we have developed 12 versions of viscosity-composition relationships with a variety of first- and second-order coefficients. Two models, one first order and one second order, are presented in this paper.
\end{abstract}

\section{VISCOSITY-COMPOSITION RELATIONSHIPS}

Viscosity-temperature relationships are important for both glass melting and glass forming. Over the wide interval of temperatures - from the glass transition temperature to the temperature at which glass is being refined-viscosity spans 12 orders of magnitude. Many approximation functions have been suggested in the literature to model the viscosity-temperature relationship. The most popular among them are the Vogel-Fulcher-Tammann equation and the Adam-Gibbs equation, ${ }^{1}$ the latter of which is more versatile and allows better fitting of high-temperature data. ${ }^{2,3}$

As has been demonstrated with various viscosity databases, both for commercial ${ }^{4,5}$ and waste glasses, ${ }^{5,6}$ high-temperature viscosity is best fitted by an Arrhenius function,

$$
\ln (\eta)=A+B / T
$$

where $\eta$ is the viscosity, $T$ is the temperature, $A$ is a constant coefficient, and $B$ is the activation energy. In Equation (1), both $A$ and $B$ are independent of temperature. Thus, for low viscosities, $\eta<10^{3} \mathrm{~Pa} \cdot \mathrm{s}$, the activation energy depends on composition only. Because the melting temperatures of glass are usually below $10 \mathrm{~Pa} \cdot \mathrm{s}$, Equation (1) fully suffices for formulating glasses to meet melt-processing constrains with respect to glass formulation as well as mathematical modeling of glass-melting furnaces. 
As has been both argued ${ }^{7}$ and demonstrated, ${ }^{2,4-6} A$ is nearly independent of composition and can be treated as constant for a specific family of glasses characterized by a restricted composition region.

Because of its simplicity, Equation (1) is ideally suited for glass formulation, especially for formulation of waste glasses that contain a large number of components.

The activation energy is usually expressed as a function of composition using the concept of partial properties. ${ }^{8}$ Thus,

$$
B=\sum_{i=1}^{N} B_{i} x_{i}
$$

where $x_{i}$ is the $i^{\text {th }}$ component's mass fraction, $B_{i}$ is the $i^{\text {th }}$ component's partial specific activation energy, and $N$ is the number of components.

Partial properties are themselves functions of compositions. For narrow ranges of mass fractions, $B_{i} \mathrm{~S}$ can be approximated as constants. For some highly interactive components, especially those with a wide range of mass fractions, $B_{i} \mathrm{~s}$ can be approximated as linear functions of composition. Thus,

$$
B_{i}=\sum_{j=1}^{N} B_{i j} X_{j}
$$

where $B_{i j}$ is the $i^{\text {th }}$ and $j^{\text {th }}$ components' second-order coefficient.

Over the past decades, a huge viscosity database has been accumulated at various laboratories in the US. The database compiled at the Pacific Northwest National Laboratory comprises over 1300 compositions with 83 components and nearly 6800 data for viscosities $<1000 \mathrm{~Pa} \cdot \mathrm{s}$ that are important for the melting process. ${ }^{9}$ Using this database and Equations (1)-(3) , we have developed 12 versions of viscosity-composition relationships with a variety of first- and second-order coefficients.

\section{DATA PREPARATION AND THE FIRST-ORDER MODEL}

The PNNL database contains both targeted and analytical compositions. Because targeted compositions are generally more accurate (weighing of analytical-grade chemicals is an accurate operation) and analytical data were not available for a number of glasses, we chose the targeted compositions for calculations.

Out of 83 components listed in the database, oxides of various elements (As, Ce, Co, Fe, Mn, Mo, $\mathrm{Pb}, \mathrm{Pr}, \mathrm{Re}, \mathrm{Rh}, \mathrm{Sb}, \mathrm{Sn}, \mathrm{Tc}, \mathrm{Tl}$, and $\mathrm{U}$ ) were listed in more than one valence state. By choosing a single valency for each of these oxides $\left(\mathrm{As}_{2} \mathrm{O}_{3}, \mathrm{Ce}_{2} \mathrm{O}_{3}, \mathrm{CoO}, \mathrm{Fe}_{2} \mathrm{O}_{3}, \mathrm{MnO}, \mathrm{MoO}_{3}, \mathrm{PbO}, \mathrm{Pr}_{2} \mathrm{O}_{3}, \mathrm{Re}_{2} \mathrm{O}_{7}, \mathrm{Rh}_{2} \mathrm{O}_{3}\right.$, $\mathrm{Sb}_{2} \mathrm{O}_{3}, \mathrm{SnO}, \mathrm{Tc}_{2} \mathrm{O}_{7}, \mathrm{Tl}_{2} \mathrm{O}$, and $\mathrm{UO}_{2}$ ), the number of components was decreased to 56 . Then we

renormalized the composition so that $\sum_{i=1}^{N} x_{i}=1$. After sorting data by viscosity, we removed from the database all data with $\eta>1050 \mathrm{~Pa} \cdot \mathrm{s}$, reducing the number of data points to 6765 .

Using Equation (1), we calculated the activation energy for each data point, i.e., each $(\eta, T)$ pair, as $B=T(\ln \eta-A)$. Then we fitted Equation (2) to data with the least-squares method, obtaining $A$ and the first-order coefficients, $B_{i}$. With all 6765 data, the coefficient of determination was $R^{2}=0.9172$. This first fit resulted in unusually high $B_{i}$ values for 17 components with $x_{i}<0.01\left(\mathrm{Cs}_{2} \mathrm{O}, \mathrm{Sb}_{2} \mathrm{O}_{3}, \mathrm{SeO}_{2}, \mathrm{Tl}_{2} \mathrm{O}\right.$, 
$\mathrm{Tc}_{2} \mathrm{O}_{7}, \mathrm{Ag}_{2} \mathrm{O}, \mathrm{RuO}_{2}, \mathrm{Pr}_{2} \mathrm{O}_{3}, \mathrm{WO}_{3}, \mathrm{As}_{2} \mathrm{O}_{3}, \mathrm{I}, \mathrm{PdO}, \mathrm{Re}_{2} \mathrm{O}_{7}, \mathrm{Rh}_{2} \mathrm{O}_{3}, \mathrm{Rb}_{2} \mathrm{O}, \mathrm{Br}, \mathrm{Nb}_{2} \mathrm{O}_{5}$ ). We have removed these components from the composition matrix.

To meet the mass-fraction relationship, $\sum_{i=1}^{N} x_{i}=1$, we evaluated two options: 1$)$ renormalizing the remaining 39 components to 1 , or 2 ) summing $x_{i}$ s of the 17 removed components into a single collected component, "Others" (total 40 components). As expected, the coefficient of determination was slightly lower with the first option $\left(R^{2}=0.9172\right)$ than with the second $\left(R^{2}=0.9176\right)$ which had one extra parameter. However, the main reason for choosing the second option was that we needed the Others component for future use when a further reduction in the number of viscosity-affecting components appeared appropriate.

Out of the remaining components, $\mathrm{SO}_{3}$ had an extremely high coefficient, $B_{\mathrm{SO}}=3.65 \times 10^{4} \mathrm{~K}$, the highest of all $B_{\mathrm{i}} \mathrm{s}$. The reason we did not initially remove $\mathrm{SO}_{3}$ from the composition matrix was its high concentration, over 2 mass \%, in some glasses. Its coefficient remained high even after we deleted two glasses with $>2.0 \% \mathrm{SO}_{3}$ from the database. The impossible $\mathrm{BSO}_{\mathrm{SO}}$ value was most likely caused by $\mathrm{SO}_{3}$ segregation and evaporation from the melts, as a result of which the targeted content of $\mathrm{SO}_{3}$ was not retained in the glass. Since replacing targeted values with analytical values did not appear practicable, we have added $\mathrm{SO}_{3}$ to Others.

In the next step, we sorted the data according to the value of $\Delta^{2}=\left(B_{M}-B_{C}\right)^{2}$, where the subscript $M$ stands for measured and $\mathrm{C}$ for calculated. After repeated resorting and refitting of Equation (2) to data with $\Delta^{2}>3.3 \times 10^{5} \mathrm{~K}^{2}$, the selection stabilized at 5909 data points, and we obtained preliminary values of $A$ and $B_{i}$ s. The coefficient of determination increased to $R^{2}=0.9712$.

For all data with $\eta<1050 \mathrm{~Pa} \cdot \mathrm{s}$, the $T$ span was from 752 to $1806{ }^{\circ} \mathrm{C}$ and the $\log (\eta / \mathrm{Pa} \cdot \mathrm{s})$ interval was $(-0.85 ; 3.02)$. For data with $\Delta^{2}<3.3 \times 10^{5} \mathrm{~K}^{2}$, the $T$ span shrank to $800-1632^{\circ} \mathrm{C}$ and the $\log (\eta / \mathrm{Pa} \cdot \mathrm{s})$ interval shrank to $(-0.51 ; 2.57)$.

Surprisingly, the composition region shrank little. Maximum mass fractions of only six components $\left(\mathrm{SiO}_{2}, \mathrm{Fe}_{2} \mathrm{O}_{3}, \mathrm{~K}_{2} \mathrm{O}, \mathrm{CaO}, \mathrm{MgO}\right.$, and $\mathrm{NiO}$ ) slightly decreased and the minimum mass fractions of $\mathrm{SiO}_{2}$ slightly increased. Fig. 1 displays the data points on the $(1 / T, \log \eta)$ surface. It shows that out of 856 rejected data points, only a few lie outside the $(1 / T, \log \eta)$ region of data selected.

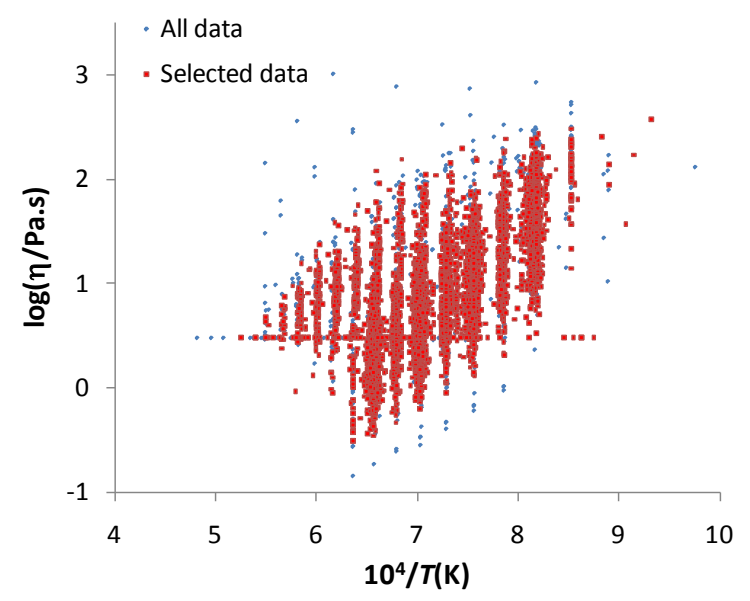

Fig. 1. Positions of $(1 / T$, $\log \eta)$ data with $\eta>1050 \mathrm{~Pa} \cdot \mathrm{s}$ and model-selected data $\left(\Delta^{2}<3.3 \times 10^{5} \mathrm{~K}^{2}\right)$

In a further attempt to eliminate components that are unlikely to influence viscosity, we sorted the components according to three criteria, $B_{i}-B_{a},\left(B_{i}-B_{a}\right) x_{i a}$ and $\left(B_{i}-B_{a}\right) x_{i m}$, where subscripts $a$ and $m$ stand for average and maximum, respectively. Components $\mathrm{Ce}_{2} \mathrm{O}_{3}, \mathrm{CoO}, \mathrm{Cr}_{2} \mathrm{O}_{3}, \mathrm{CuO}, \mathrm{Eu}_{2} \mathrm{O}_{3}, \mathrm{Ga}_{2} \mathrm{O}_{3}, \mathrm{HfO}_{2}$, 
$\mathrm{MoO}_{3}, \mathrm{Nd}_{2} \mathrm{O}_{3}, \mathrm{Sm}_{2} \mathrm{O}_{3}, \mathrm{SnO}, \mathrm{ThO}_{2}, \mathrm{TiO}_{2}, \mathrm{UO}_{2}$, and $\mathrm{Y}_{2} \mathrm{O}_{3}$ had low values of all these criteria. After removing these components to Others, the number of components shrank to 24, including Others. Repeated fitting and $\Delta^{2}$ sorting until the number of outliers stabilized at $\Delta^{2}>3.3 \times 10^{5} \mathrm{~K}^{2}$ resulted in the selection of 5893 data points. Both the $T$ span and $\log (\eta / \mathrm{Pa} \cdot s)$ interval remained unaffected by removal of the noninfluential components. Likewise, the composition region remained unchanged except for the maximum mass fraction of $\mathrm{SiO}_{2}$, which slightly decreased.

The component coefficients of the resulting first-order model, obtained by fitting Equations (1) and (2) to selected data, are listed in Table 1 . The value of the A coefficient is -11.193 . The coefficient of determination, $R^{2}=0.9710$, remained high. The maximum component mass fractions, listed in Table I, represent the model validity region. The minimum component mass fraction is 0 for all components except $\mathrm{SiO}_{2}(0.194)$ and $\mathrm{Na}_{2} \mathrm{O}(0.008)$.

TABLE I. Component Coefficients and Maximum Component Mass Fractions

\begin{tabular}{|l|c|c|l|c|c|l|c|c|}
\hline & $B_{i}\left(10^{4} \mathrm{~K}\right)$ & $x_{i m}$ & & $B_{i}\left(10^{4} \mathrm{~K}\right)$ & $x_{i m}$ & & $B_{i}\left(10^{4} \mathrm{~K}\right)$ & $x_{i m}$ \\
\hline $\mathrm{SiO}_{2}$ & 2.999 & 0.628 & $\mathrm{Bi}_{2} \mathrm{O}_{3}$ & 1.425 & 0.162 & $\mathrm{Gd}_{2} \mathrm{O}_{3}$ & 1.271 & 0.077 \\
\hline $\mathrm{Na}_{2} \mathrm{O}$ & -0.036 & 0.351 & $\mathrm{ZrO}_{2}$ & 2.707 & 0.158 & $\mathrm{~F}$ & -0.469 & 0.060 \\
\hline $\mathrm{Fe}_{2} \mathrm{O}_{3}$ & 1.553 & 0.264 & $\mathrm{MnO}$ & 0.458 & 0.136 & $\mathrm{~V}_{2} \mathrm{O}_{5}$ & 1.396 & 0.060 \\
\hline $\mathrm{Al}_{2} \mathrm{O}_{3}$ & 3.500 & 0.266 & $\mathrm{P}_{2} \mathrm{O}_{5}$ & 2.644 & 0.131 & $\mathrm{La}_{2} \mathrm{O}_{3}$ & 0.656 & 0.050 \\
\hline $\mathrm{SrO}$ & 1.008 & 0.299 & $\mathrm{ZnO}$ & 1.034 & 0.099 & $\mathrm{BaO}$ & 0.662 & 0.047 \\
\hline $\mathrm{K}_{2} \mathrm{O}$ & 0.802 & 0.100 & $\mathrm{PbO}$ & 0.978 & 0.097 & $\mathrm{CdO}$ & 0.740 & 0.040 \\
\hline $\mathrm{B}_{2} \mathrm{O}_{3}$ & 0.319 & 0.202 & $\mathrm{MgO}$ & 1.151 & 0.082 & NiO & 0.785 & 0.021 \\
\hline $\mathrm{CaO}$ & 0.533 & 0.150 & $\mathrm{Li}_{2} \mathrm{O}$ & -3.908 & 0.090 & Others & 1.771 & 0.182 \\
\hline
\end{tabular}

\section{SECOND-ORDER MODEL}

For the second-order model, we have selected 8 major components with the highest values of $\left(B_{i}-B_{a}\right) x_{i a}$. These components are $\mathrm{SiO}_{2}, \mathrm{Na}_{2} \mathrm{O}, \mathrm{Li}_{2} \mathrm{O}, \mathrm{B}_{2} \mathrm{O}_{3}, \mathrm{Al}_{2} \mathrm{O}_{3}, \mathrm{CaO}, \mathrm{ZrO}_{2}$, and $\mathrm{Fe}_{2} \mathrm{O}_{3}$. The full second-order matrix has $N_{B}=(1 / 2) N(N+1)$ coefficients. Thus, for $N=8, N_{B}=36$.

Various versions of the second-order model were subsequently developed:

Model 0. In the baseline model, the first-order terms for major components were left in the fit because does not have second-order terms for 15 minor components $\left(\mathrm{SrO}, \mathrm{K}_{2} \mathrm{O}, \mathrm{Bi}_{2} \mathrm{O}_{3}, \mathrm{MnO}, \mathrm{P}_{2} \mathrm{O}_{5}, \mathrm{ZnO}\right.$, $\mathrm{PbO}, \mathrm{MgO}, \mathrm{Gd}_{2} \mathrm{O}_{3}, \mathrm{~F}, \mathrm{~V}_{2} \mathrm{O}_{5}, \mathrm{La}_{2} \mathrm{O}_{3}, \mathrm{BaO}, \mathrm{CdO}, \mathrm{NiO}$ ).

Model 1. The first-order terms of $\mathrm{SiO}_{2}, \mathrm{Na}_{2} \mathrm{O}, \mathrm{Li}_{2} \mathrm{O}, \mathrm{B}_{2} \mathrm{O}_{3}, \mathrm{Al}_{2} \mathrm{O}_{3}, \mathrm{CaO}, \mathrm{ZrO}_{2}$, and $\mathrm{Fe}_{2} \mathrm{O}_{3}$, which would be, by Equation (3), redundant in the full second-order model, were removed while keeping the list of minor components unchanged.

Model 2. To further simplify the second-order model, we removed second-order terms with $\left|B_{i}-B_{a}\right| /\left(B_{a}-S\right)$ $<1$, where $B_{a}$ is the $B$ average and $S$ is the standard deviation.

Model 3. In another version of the second-order model, in addition to removing first-order terms of $\mathrm{SiO}_{2}, \mathrm{Na}_{2} \mathrm{O}, \mathrm{Li}_{2} \mathrm{O}, \mathrm{B}_{2} \mathrm{O}_{3}, \mathrm{Al}_{2} \mathrm{O}_{3}, \mathrm{CaO}, \mathrm{ZrO}_{2}$, and $\mathrm{Fe}_{2} \mathrm{O}_{3}$, we also removed minor components with $\left|B_{i}-B_{a}\right| /\left(B_{a}-S\right)<0.5\left(\mathrm{Bi}_{2} \mathrm{O}_{3}, \mathrm{PbO}, \mathrm{Gd}_{2} \mathrm{O}_{3}, \mathrm{~V}_{2} \mathrm{O}_{5}, \mathrm{La}_{2} \mathrm{O}_{3}, \mathrm{BaO}, \mathrm{CdO}, \mathrm{NiO}\right)$ and added them to Others.

Model 4. Models 0 to 3 started with all 6765 data. In Models 4 to 8, we removed from the database glasses with high fractions of minor components. The number of data decreased to 5969. Without removing the first-order terms of $\mathrm{SiO}_{2}, \mathrm{Na}_{2} \mathrm{O}, \mathrm{Li}_{2} \mathrm{O}, \mathrm{B}_{2} \mathrm{O}_{3}, \mathrm{Al}_{2} \mathrm{O}_{3}, \mathrm{CaO}, \mathrm{ZrO}_{2}$, and $\mathrm{Fe}_{2} \mathrm{O}_{3}$, we kept 
removing, one-by-one, compositions in which $x_{i m} / x_{i a}>20$. Thus, glasses with high fractions of $\mathrm{Bi}_{2} \mathrm{O}_{3}, \mathrm{~V}_{2} \mathrm{O}_{5}, \mathrm{PbO}, \mathrm{SrO}, \mathrm{Gd}_{2} \mathrm{O}_{3}, \mathrm{BaO}, \mathrm{MnO}$, and $\mathrm{La}_{2} \mathrm{O}_{3}$ were deleted.

Model 5. Here we moved to Others the minor components $\mathrm{V}_{2} \mathrm{O}_{5}, \mathrm{Bi}_{2} \mathrm{O}_{3}, \mathrm{Gd}_{2} \mathrm{O}_{3}, \mathrm{PbO}$, and $\mathrm{BaO}$ for which $x_{a}\left|B_{i}-B_{a}\right| /\left(B_{a}-S\right)<8.74$, a value for Others in Model 4.

Model 6. Continuing the component reduction, we moved to Others all minor components except SrO, $\mathrm{K}_{2} \mathrm{O}, \mathrm{P}_{2} \mathrm{O}_{5}, \mathrm{ZnO}, \mathrm{MgO}$, and $\mathrm{F}$.

Model 7. In this version of Model 6, we removed the first-order coefficients of the major components.

Model 8. With the same set of data and coefficients as in Model 6, only data with $\Delta^{2}>3.3 \times 10^{4} \mathrm{~K}^{2}$

(Model 8a) and $\Delta^{2}>3.3 \times 10^{3} \mathrm{~K}^{2}$ (Model 8b) were selected for model fitting.

The space limitation does not allow us to report details for all these model versions. Tables II and III list the component coefficients for Model 6. The number of outliers stabilized at $\Delta^{2}>3.3 \times 10^{5} \mathrm{~K}^{2}$ with 5867 data points, $A=-11.373$, and $R^{2}=0.9795$. The component effects are displayed in Fig. 2 (the spider plot) in terms of $B$ versus the mass fractions of components added to the average composition of all glasses selected for model fitting. Note that the effects of $\mathrm{B}_{2} \mathrm{O}_{3}, \mathrm{CaO}$, and $\mathrm{SrO}$ are similar.

TABLE II. Model 6 Second-Order Coefficients, $10^{-4} B_{i j}(\mathrm{~K})$

\begin{tabular}{|l|r|r|r|r|r|r|r|r|}
\hline & $\mathrm{SiO}_{2}$ & $\mathrm{Na}_{2} \mathrm{O}$ & $\mathrm{B}_{2} \mathrm{O}_{3}$ & $\mathrm{Al}_{2} \mathrm{O}_{3}$ & $\mathrm{Fe}_{2} \mathrm{O}_{3}$ & $\mathrm{ZrO}_{2}$ & $\mathrm{Li}_{2} \mathrm{O}$ & \multicolumn{1}{c|}{$\mathrm{CaO}$} \\
\hline $\mathrm{SiO}_{2}$ & 0.27 & -1.66 & -1.28 & 0.88 & 0.62 & 2.29 & -5.11 & -0.56 \\
\hline $\mathrm{Na}_{2} \mathrm{O}$ & & 1.99 & -1.95 & 0.14 & 1.96 & 1.96 & 11.97 & 2.96 \\
\hline $\mathrm{B}_{2} \mathrm{O}_{3}$ & & & 4.33 & -1.27 & 2.20 & 0.53 & 1.45 & 0.93 \\
\hline $\mathrm{Al}_{2} \mathrm{O}_{3}$ & & & & 0.98 & 1.91 & 0.46 & -8.81 & -1.12 \\
\hline $\mathrm{Fe}_{2} \mathrm{O}_{3}$ & & & & & 1.43 & -0.09 & -1.49 & 1.60 \\
\hline $\mathrm{ZrO}_{2}$ & & & & & & -1.17 & -2.79 & 0.85 \\
\hline $\mathrm{Li}_{2} \mathrm{O}$ & & & & & & & 27.82 & 6.08 \\
\hline $\mathrm{CaO}$ & & & & & & & & 0.38 \\
\hline
\end{tabular}

TABLE III. Model 6 First-Order Coefficients

\begin{tabular}{|l|c|l|c|l|c|}
\hline & $10^{-4} B_{i}(\mathrm{~K})$ & & $10^{-4} B_{i}(\mathrm{~K})$ & & $10^{-4} B_{i}(\mathrm{~K})$ \\
\hline $\mathrm{SiO}_{2}$ & 3.15 & $\mathrm{ZrO}_{2}$ & 1.54 & $\mathrm{P}_{2} \mathrm{O}_{5}$ & 2.64 \\
\hline $\mathrm{Na}_{2} \mathrm{O}$ & -0.22 & $\mathrm{Li}_{2} \mathrm{O}$ & -4.38 & $\mathrm{ZnO}$ & 1.59 \\
\hline $\mathrm{B}_{2} \mathrm{O}_{3}$ & 0.37 & $\mathrm{CaO}$ & 0.17 & $\mathrm{MgO}$ & 1.37 \\
\hline $\mathrm{Al}_{2} \mathrm{O}_{3}$ & 3.27 & $\mathrm{SrO}$ & 0.74 & $\mathrm{~F}$ & -0.01 \\
\hline $\mathrm{Fe}_{2} \mathrm{O}_{3}$ & 0.53 & $\mathrm{~K}_{2} \mathrm{O}$ & 1.03 & Others & 1.65 \\
\hline
\end{tabular}

\section{CONCLUSIONS}

The PNNL waste-glass property database is an invaluable source of data. We have evaluated data for viscosity as a function of temperature and composition and developed 12 versions of a mathematical model (two first-order models and ten second-order models) for the activation energy as a function of glass composition. Tables I through III present the component coefficients for two representative models. 

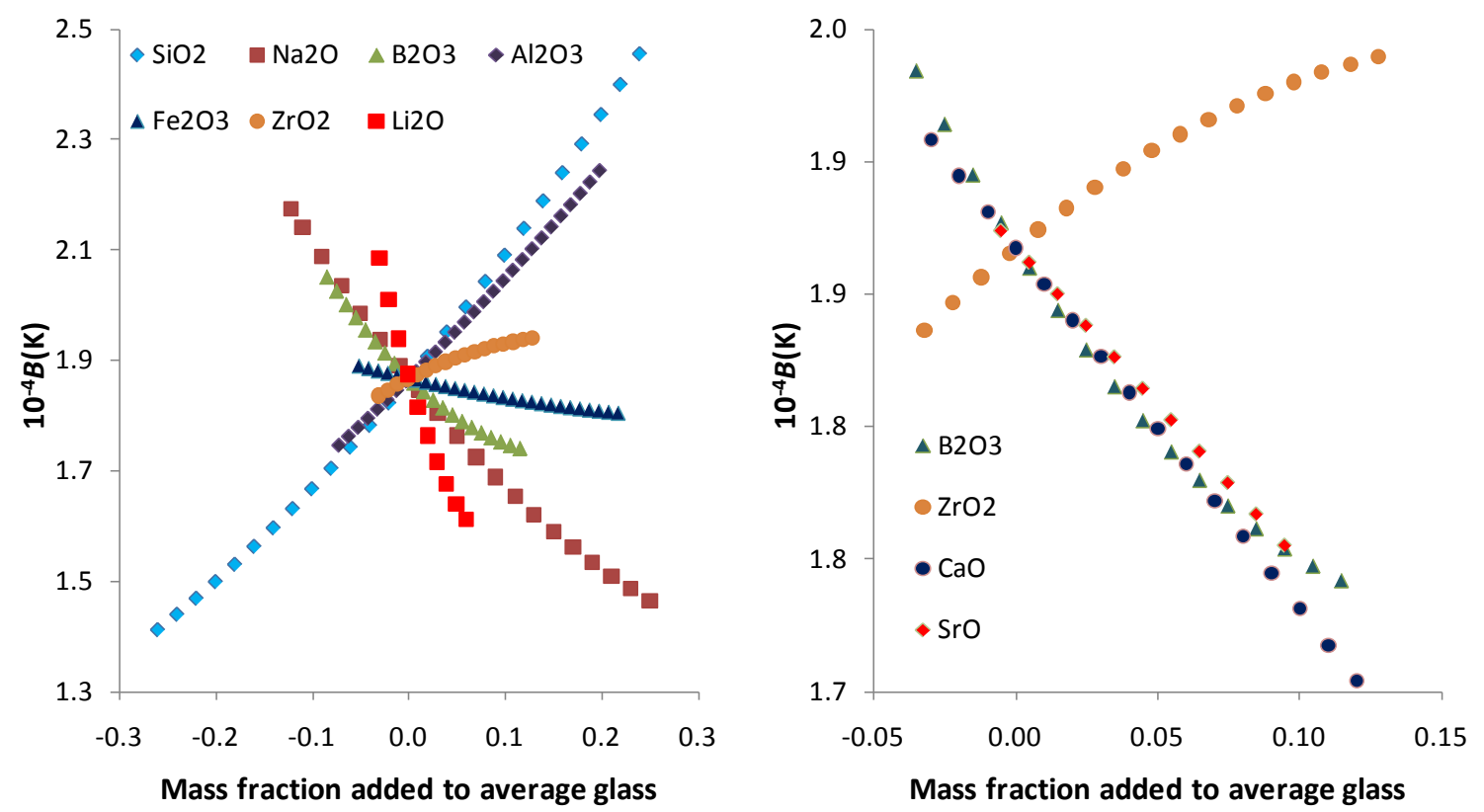

Fig. 2. Spider plot: Effects of component addition to average glass composition.

\section{ACKNOWLEDGEMENTS}

This study was supported by WCU (World Class University) program through the National Research Foundation of Korea funded by the Ministry of Education, Science and Technology (R31 - 30005).

\section{REFERENCES}

1. G. ADAM and J. H. GIBBS, "On the temperature dependence of cooperative relaxation properties in glass-forming liquids,” J. Chem. Phys., 43, 139 (1965).

2. P. HRMA, "Glass viscosity as a function of temperature and composition: A model based on AdamGibbs equation,” J. Non-Cryst. Solids, 354, 3389-3399 (2008).

3. D. R. NEUVILLE, "Viscosity, structure and mixing in (Ca, Na) silicate melts," Chem. Geol., 229, 28 (2006).

4. P. HRMA, "High-temperature Viscosity of Commercial Glasses,” Ceramics Silikaty, 50, 57 (2006).

5. P. HRMA, “Arrhenius Model for High-Temperature Glass Viscosity with a Constant PreExponential Factor,” J. Non-Cryst. Solids, 354, 1962 (2008).

6. P. HRMA, B. M. ARRIGONI, M. J. SCHWEIGER, “Viscosity of many-component glasses,” J. Non-Cryst. Solids, 355, 891 (2009).

7. C.A. ANGELL, "Structural instability and relaxation in liquid and glassy phases near the fragile liquid limit,” J. Non-Cryst. Solids, 102205 (1988).

8. P. HRMA, "Empirical Models and Thermodynamic Constitutive Functions for High-Level Waste Glass Properties,” Ceram. Trans., 87, 245 (1998).

9. J. D. VIENNA, A. FLUEGEL, D. S. KIM, P. HRMA, Glass Property Data and Models for Estimating High-Level Waste Glass Volume, PNNL-18501, Pacific Northwest National Laboratory, Richland, Washington (2009). 